PROBLEMS

OF MANAGEMENT IN THE $21^{\text {st }}$ CENTURY Vol. 9, No. 3, 2014

206

\title{
ATTITUDES OF SHOP FLOOR EMPLOYEES TOWARD WOMEN MANAGERS IN FUEL DEPOTS: A CASE OF THE FUEL DEPOTS IN LUBUMBASHI, DEMOCRATIC REPUBLIC OF THE CONGO
}

\author{
Stephen N. M. Nzuve \\ University of Nairobi, Kenya \\ E-mail: snmnzuve@uonbi.ac.ke \\ Solomon Chepsongol Kelwon \\ Democratic Republic of the Congo \\ E-mail: scckelwon@yahoo.com
}

\begin{abstract}
The International Labour Organization and all organizations of human rights advocate against any form of negative attitude in employment based on gender, its terms, promotion and relations. Shop floor employees play a very important role in the daily advancement and profitability of an organisation. The purpose of this study was to establish the attitude of shop floor employees toward women managers in fuel depots in Lubumbashi, Democratic Republic of the Congo. The study adopted a descriptive survey design with the population consisting of one hundred and ninety three (193) shop floor employees. A semi structured questionnaire was used to collect primary data. In total one hundred and twenty one (121) shop floor employees responded yielding a response rate of sixty three percent (63\%). The findings of this study indicate that a negative attitude toward woman managers is prevalent in the Fuel Depots of Lubumbashi, Democratic Republic of the Congo. At the fuel depots, the number of women working was less than a third of the males. In spite of this, women managers are rated higher in management qualities and are considered to be more honest, diligent, compassionate, creative and intelligent when compared to their male counterparts. The study recommends a culture change among employees in fuel depots in Lubumbashi in order to enable them perceive women as equal partners at the work place.
\end{abstract}

Key words: attitude, gender, shop floor employees, discrimination, work place safety and fuel depot.

\section{Introduction}

\section{Background of the Study}

Successful organizations are those which have well developed manpower. Employees are a critical asset in a company as a company's future is determined, among other factors, by the manpower it has and how well the same is managed (Srivastava, 2007). Employers are expected to recruit staff without any form of discrimination on gender, colour, race, tribe or religion. Promotions and payment of women managers should be done without any favour. Employers are supposed to offer equal opportunity employment or discrimination based on sex or any other consideration (Silverstein \& Kaitesayre, 2009).

The numbers of female executives in decision making positions has tremendously improved with more women being highly qualified and employed as Chief Executive Officers and 
in other key positions of leadership across all industries. According to Beardwell and Holden (1997), in 1989 only 44 percent of women were in employment. It reached 50 percent in 2000 yet only 11 percent were in general management. Only 1 percent of women were at chief executive level as reported by Davidson and Cooper (1992).

Graham \& Bennett (1995) define attitude as when somebody leans towards a perception. It is how somebody views and reacts to circumstances. It is closely related to perception which is defined as an ability to see, hear or become aware (www.oxforddictionaries.com). It is the way that something is viewed, learned or defined. It is one of the factors in the perceiver (Nzuve, 2007). An attitude is how somebody views or thinks about something, a place or how a thing or work should be done.

A fuel depot is where companies store their fuel in bulk. When fuel is imported, it is received in a fuel depot and stored in big massive tanks which are securely kept before redistribution for sale. The majority of diesel clients are mining companies in Lubumbashi, Katanga Province. Their consumption is high compared to fuel used for commercial purposes. Other clients of fuel depots are petrol stations and local clients. Depots are very sensitive fuel installations where the highest level of safety is maintained.

Shop floor employees are in the lower cadres of employment in an organizational establishment. They are involved in production of goods and services at the initial stages like in a factory or machine shop with the duties and expectations being among others to receive instructions from management, be orderly, pay attention to detail and be conversant with their duties which they have to do (http://en.wikipedia.org/wiki/shop). In addition, it is expected that they are vigilant, safety conscious, and report promptly when exposed to dangerous machines or other dangers. This is critical in fuel depots where safety is paramount. The attitudes which shop floor employees have towards women managers is important as negative attitude towards women managers who have increased in number exponentially will impact negatively to the company and vice versa.

\section{Statement of the Problem}

Graham and Bennett (1995) argue that group attitudes are developed over time and may be changed. Social groups thus hold attitudes that are appropriate to them as per their standing in society and circumstances shaping the attitudes. It is possible to influence People's thinking and attitudes. Attitude of employees is important at work and this has an impact on the way they view management or managers. When attitude of employees or even managers is known, it becomes easier to change them.

Kalii (1997) researched on executives' perceptions on women managers and established a predominant belief that the workplace is a man's domain and women belong to the home and suggested that further research should be done on the views of employees not in authority. Most of the studies done are on managers as respondents. This research gap motivated the study on attitude of shop floor employees toward women managers.

\section{Aim of the Study}

To determine the attitude of shop floor employees toward women managers in fuel depots in Lubumbashi, Democratic Republic of the Congo. 
Stephen N. M. NZUVE, Solomon Chepsongol KELWON. Attitudes of Shop Floor Employees toward Women Managers in Fuel Depots: A Case of the Fuel Depots in Lubumbashi, Democratic Republic of the Congo

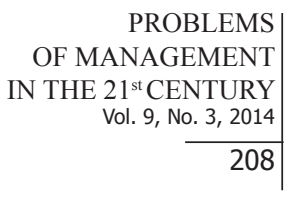

\section{Contributions of the Study}

The findings of this study will be of value to various stakeholders:-

a) In changing negative attitude amongst employees toward women managers.

b) In assisting women managers to understand how their employees rate their leadership qualities.

c) It will also help them to adopt better management strategies towards employees.

d) In the long run, it could lead to more women claiming a stake in male dominated arenas of management.

e) This study apart from enhancing our understanding of attitudes towards women managers, may add value to knowledge for researchers and academicians who may use it for reference purposes.

f) It will also help in the knowledge of managing across cultures. Businesses are nowadays managed globally. Due to an advance in technology, markets are now a global village. Human resources are assets of companies and managing them well is beneficial to organizations.

g) The study will help in the growth of fuel companies and other industries.

\section{Methodology of Research}

The study adopted a descriptive census survey design over a period of one month with a population of one ninety three (193) shop floor employees located in a single town, Lubumbashi which is the second largest city in Democratic Republic of the Congo. As the population was not high and sparsely distributed, the study opted for the census survey. As the census survey included all the shop floor employees it was easy to administer the semi structured questionnaire through the drop and pick later method.

\section{Respondents Characteristics}

One hundred and ninety three (target population) questionnaires were administered to shop floor employees in eleven (11) fuel depots with a $64 \%$ response rate. $76 \%$ of the respondents were men while $24 \%$ were women. Age distribution was $45 \%$ of the respondents aged $27-34$ years, $25 \%$ aged between $35-44$ years, twenty nine percent $(22 \%)$ aged over 45 years and $8 \%$ were between $18-26$ years. $79 \%$ of the respondents were married, $20 \%$ were single and $1 \%$ widowers or divorced. $37.2 \%$ of the respondents had attained university education, $33.1 \%$ had been up to college with $28.1 \%$ having secondary education as their highest level of education. $1.7 \%$ had basic education (up to primary level). $34 \%$ had been employees in their respective companies for $4-5$ yrs while $32 \%$ for between 1 and 3 yrs, 20\% for more than 5 years and those who had worked in their respective companies for less than one year were $14 \%$. Cumulatively, the highest percentage (54\%) of the shop floor employees had been with their respective companies for more than four years.

\section{Results of Research}

This chapter shows the results of the study using figures and tables for illustration purposes. 
Stephen N. M. NZUVE, Solomon Chepsongol KELWON. Attitudes of Shop Floor Employees toward Women Managers in Fuel Depots: A Case of the Fuel Depots in Lubumbashi, Democratic Republic of the Congo

\section{Organizational Gender Composition of Fuel Companies in Lubumbashi}

The majority of the managers in each of the companies are male with some companies having no women managers as well as shop floor employees.

Table 1. Organizational gender composition of fuel companies in Lubumbashi.

\begin{tabular}{lllllll}
\hline & Fuel Depot & $\begin{array}{l}\text { No of Women } \\
\text { Shop Floor } \\
\text { Employees }\end{array}$ & $\begin{array}{l}\text { No of Men } \\
\text { Shop Floor } \\
\text { Employees }\end{array}$ & $\begin{array}{l}\text { No of Women } \\
\text { Managers }\end{array}$ & $\begin{array}{l}\text { No of Men } \\
\text { Managers }\end{array}$ & $\begin{array}{l}\text { \% of Women } \\
\text { Managers Vs } \\
\text { Men Managers } \\
\text { (Managerial) }\end{array}$ \\
\hline 1 & HASS Petroleum & 8 & 29 & 2 & 5 & 40 \\
\hline 2 & SEP-CONGO & 3 & 30 & 2 & 6 & 33.3 \\
\hline 3 & Mulycap Petroleum & 3 & 6 & 1 & 3 & 33.3 \\
\hline 4 & ENGEN Petroleum & 1 & 2 & 0 & 2 & 0 \\
\hline 5 & 'AN Company' & 1 & 18 & 0 & 5 & 0 \\
\hline 6 & UNITED Petroleum & 1 & 14 & 1 & 4 & 25 \\
\hline 7 & EXPRESS OIL & 2 & 22 & 1 & 5 & 20 \\
\hline 8 & MOGAS OIL & 2 & 8 & 2 & 4 & 50 \\
\hline 9 & CONGO PETROL & 3 & 21 & 0 & 6 & 0 \\
\hline 10 & SARP OIL & 2 & 7 & 1 & 4 & 25 \\
\hline 11 & SPC & 2 & 8 & 1 & 3 & 33.3 \\
\hline
\end{tabular}

On average, across all the companies in the survey, there are more men than women whether as shop floor employees or in management with a range spread of between 0 and $50 \%$ with a near normal distribution.

\section{Shop Floor Employees Attitude toward Women Managers}

A five point Likert scale was used to rate the attitude of shop floor employees toward women managers where $1=$ Strongly Agree (SA), $2=$ Agree (A), $3=$ Neither Agree nor Disagree $(\mathrm{N} \mathrm{A} / \mathrm{D}), 4=$ Disagree (D), $5=$ Strongly Disagree $(\mathrm{SD})$. The highest score on the scale (5) was for 'strongly disagree' which indicates an unfavourable attitude; 3 indicate a neutral or undecided stand while 1 strongly agree indicates a favourable attitude. 
Stephen N. M. NZUVE, Solomon Chepsongol KELWON. Attitudes of Shop Floor Employees toward Women Managers in Fuel Depots: A Case of the Fuel Depots in Lubumbashi, Democratic Republic of the Congo

PROBLEMS

OF MANAGEMENT

IN THE $21^{\text {st }}$ CENTURY Vol. 9, No. 3, 2014

210

Table 2. Shop floor employees' attitude toward women managers.

\begin{tabular}{lllllll}
\hline Shop floor employees attitude toward women managers & SA & A & N A/D & D & SD & Mean \\
\hline Liked & 12 & 20 & 11 & 21 & 36 & 3.47 \\
\hline $\begin{array}{l}\text { Cannot Easily Penetrate into some jobs because men have } \\
\text { dominated them }\end{array}$ & 11 & 12 & 13 & 37 & 26 & 3.64 \\
\hline Are not exposed to the same training facilities as men & 6 & 18 & 9 & 27 & 40 & 2.23 \\
\hline $\begin{array}{l}\text { Restricted in employment and cannot easily be promoted } \\
\text { further }\end{array}$ & 9 & 27 & 12 & 28 & 24 & 3.37 \\
\hline Get promoted through hard work. & 8 & 14 & 26 & 22 & 31 & 3.52 \\
\hline Those who are lucky get promotion just by chance & 14 & 15 & 8 & 28 & 35 & 3.96 \\
\hline $\begin{array}{l}\text { Those who are pregnant become ineffective } \\
\text { Generally view themselves as not superior as men }\end{array}$ & 23 & 27 & 12 & 24 & 13 & 3.20 \\
\hline $\begin{array}{l}\text { Attain positions by copying men's traits like determination, } \\
\text { decisiveness, tireless \& authoritative }\end{array}$ & 17 & 25 & 24 & 21 & 13 & 2.88 \\
\hline $\begin{array}{l}\text { Tend to be naturally poorer than men at reading facial expres- } \\
\text { sions for clues to the owner's state of mind }\end{array}$ & 12 & 19 & 24 & 28 & 17 & 3.21 \\
\hline $\begin{array}{l}\text { Been encouraged by society to see their future in terms of } \\
\text { caring to their families }\end{array}$ & 7 & 17 & 25 & 25 & 26 & 2.55 \\
\hline $\begin{array}{l}\text { Poor in nurturing clients unlike when nurturing their children } \\
\text { Erratic, too emotional and cannot make Sound decisions }\end{array}$ & 24 & 22 & 21 & 22 & 11 & 2.76 \\
\hline $\begin{array}{l}\text { Are exposed to a lot of stress because of family commitments } \\
\text { and work responsibilities }\end{array}$ & 22 & 36 & 17 & 12 & 13 & 2.56 \\
\hline $\begin{array}{l}\text { Hated by women as their leaders } \\
\text { Rated poorly in management qualities such as honesty, intel- } \\
\text { ligence, diligence, compassion and creativity }\end{array}$ & 3 & 5 & 24 & 43 & 25 & 3.81 \\
\hline $\begin{array}{l}\text { Women Managers should be beautiful. Helps improve levels of } \\
\text { cooperation. }\end{array}$ & 9 & 12 & 13 & 33 & 33 & 3.68 \\
\hline
\end{tabular}

Respondents felt that women managers are exposed to the same training with a mean score of 2.23 implying that irrespective of gender, male and women managers have the same training since the position of management has specific trainings, thus women managers were not disadvantaged on their training.

Women cannot easily penetrate into some jobs because men have dominated them, scored a mean of 3.64 indicating that most the respondents agreed with the statement. The same percentage of respondents disagreed that women are lucky and get promotion just by chance and that women are not supportive, sensitive or emphatic. Respondents felt that women in high positions attain the status not by sheer luck but by hard work. The respondents feel that women managers are supportive. This can be seen from the results of the study which showed that women managers are being rated highly on management skills.

However, women are encouraged by society to see their future in terms of caring for their families and homes and thus they tend to shy away from positions that would require a lot of input in terms of time and energy. Women are also not restricted in employment and get promoted based on competence and are generally viewed as equals to men, best in nurturing clients as they do to their children, tend to be naturally better than men at reading facial expressions for clues to the owner's state of mind and opinion.

The respondents disagree that women are erratic, too emotional and cannot make sound decisions but agree that women managers are exposed to a lot of stress because of family com- 
mitments and also work responsibilities and that they attain positions by copying men's traits like determination, decisiveness, tireless work ethic, and effective use of authority. Nevertheless the respondents rated women as rating higher in management qualities like honesty and intelligence with the weighted mean being 3.81 (agree).

However the respondents agreed that women managers in fuel depots become ineffective when pregnant and experience additional challenges when dealing with female shop floor employees.

\section{Conclusions and Implications}

The findings of this study indicate that gender discrimination thrives in the Democratic Republic of the Congo with women being at the receiving end as the number of women working in the fuel depots is less than a third of the number of men working in the same. Nevertheless, women managers are rated higher in management qualities and are considered to be more honest, diligent, compassionate, creative and intelligent when compared to their male counterparts. Both genders agreed on positive attribute of women managers. Another attitude which both genders agreed on is that women leaders have to pay more attention when dealing with women shop floor employees.

The study recommends that similar studies be undertaken in other sectors in Democratic Republic of the Congo and Africa. This would go a long in enhancing our understanding of attitude towards women managers.

\section{Recommendation}

The findings of the study have shown that both males and female managers can perform well. Negative attitudes should be discouraged. Fuel Companies should be encouraged that women need to be employed as managers for it has been confirmed by research that they are effective in management.

\section{References}

Beardwell, I., \& Holden, L. (1997). Human resource management: A contemporary perspective, 2nd edition. London: Pitman Publishing.

Davidson, M., \& Cooper, C. (1992). Shattering the glass ceiling: The woman manager. London: Paul Chapman Publishing.

Graham, H. T., \& Bennett, R. (1995). Human resources management: The M+E handbook. London: Pitman Publishing, Longman Group.

Kalii, F. N. (1997). Factors which bank executives perceive as hindering the career progress of women and their attitudes towards female managers: The case of commercial banks in Kenya. Unpublished MBA Research Project, University of Nairobi.

Nzuve, Stephen N. M. (2007). Elements of organizational behaviour. Nairobi: University of Nairobi Press.

Srivastava, Sh. (2007). Women in workforce: Work and family conflict. Management and Labour Studies, 32 (4), 411-421. Doi:101177/0258042x0703200401.

Advised by Judita Stankutè, SMC „Scientia Educologica“, Lithuania

Received: October 12, 2014

Accepted: December 26, 2014 
Stephen N. M. NZUVE, Solomon Chepsongol KELWON. Attitudes of Shop Floor Employees toward Women Managers in Fuel Depots: A Case of the Fuel Depots in Lubumbashi, Democratic Republic of the Congo

OF MANA

IN THE $21^{\text {st }}$ CENTURY

Vol. 9, No. 3, 2014

212

Stephen N. M. Nzuve BSc, MSc, DBA, Associate Professor, Department of Business Administration, School of Business, University of Nairobi, Kenya.

E-mail: snmnzuve@uonbi.ac.ke

Website: http://profiles.uonbi.ac.ke/snmnzuve

Solomon C. Kelwon BBA, MBA, Operation, Health, Safety and Environment Manager, CongoPetrol, Democratic Republic of the Congo.

E-mail: scckelwon@yahoo.com 